\section{Barbara Rzepka}

Monastero di SS. Trinità, via Morandini 44, 52014 Poppi (AR)

barbarabasamon@yahoo.it

ORCID: 0000-0003-0813-0195

DOI: http://dx.doi.org/10.12775/BPTh.2018.007

\section{Biblica}

et

Patristica

Thoruniensia

11 (2018) 2: 147-158

ISSN (print) 1689-5150

ISSN (online) 2450-7059

\title{
Pytanie o właściwą metodologię analizy narracyjnej
}

\section{Question on the appropriate methodology in narrative analysis}

\begin{abstract}
Abstrakt. Właściwe użycie metody analizy tekstu zakłada jego podstawową znajomość, dlatego na wstępie zostanie przedstawiona ogólna charakterystyka Biblii hebrajskiej jako literatury starożytnej i niektóre zagadnienia dotyczące metodologii analizy tekstów biblijnych. Następnie kompleksowo zostaną ukazane różne aspekty analizy narracyjnej, jej kolejne etapy w zastosowaniu do tekstów Biblii hebrajskiej oraz narzędzia, jakimi ta metoda dysponuje w odkrywaniu indywidualnych cech danej narracji. Prezentacji metodologii analizy narracyjnej towarzyszyć będzie szeroki wachlarz tekstów i przykładów jej zastosowania. Na zakończenie podejmiemy pytanie o możliwość wypracowania jakiejś jednej procedury badawczej w analizie narracji biblijnych.
\end{abstract}

\begin{abstract}
The appropriate use of the method of text analysis presupposes its fundamental knowledge, for this reason the characteristics of the Bible as ancient literature and some themes concerning the methodology of the analysis of the biblical text will be presented initially. Subsequently, various aspects of narrative analysis, its stages in application to the texts of the Hebrew Bible, and the tools the narrative method has to highlight the particular characteristics of a given narrative will be presented in an overall way. The presentation of the narrative analysis will be accompanied by a wide range of texts and examples of the application of the method. In conclusion, the question on the possibility of elaborating a single research procedure in narrative analysis will be taken into consideration.
\end{abstract}

Słowa kluczowe: podejście synchroniczne; analiza narracyjna; opowiadanie; fabuła; czytelnik.

Keywords: synchronic approach; narrative analysis; plot; narration; reader. 


\section{Wprowadzenie}

Tobie żal krzewu, którego nie uprawiałeś i nie wyhodowałeś, który w nocy \ wyrósł i w nocy zginął. A czyż Ja nie powinienem mieć litości nad Niniwą, wielkim miastem, gdzie znajduje się więcej niż sto dwadzieścia tysięcy ludzi, którzy nie odróżniają swej prawej ręki od lewej, a nadto mnóstwo zwierząt?” (Jon 4,11) - tym pytaniem Boga kończy się Księga Jonasza. Jaką odpowiedź dał Jonasz? Nie wiemy. Księga kończy się pytaniem bez odpowiedzi. Kto da odpowiedź na to pytanie Boga? - Tego typu problematyką zajmuje się analiza narracyjna. Dysponuje ona narzędziami pozwalającymi zrozumieć, że to pytanie Boga nie jest skierowane tylko do Jonasza, ale też do czytelnika, który towarzyszył Jonaszowi w całej jego drodze, który może myśli podobnie jak Jonasz i teraz staje wobec takiego pytania Boga. Jaka będzie jego odpowiedź? Księga Jonasza zaprasza do nawrócenia. Wszyscy się w niej nawracają: marynarze, Niniwici, sam Bóg zmienił swój wyrok, tylko Jonasz pozostaje niewzruszony. Woli umrzeć, aniżeli żyć w tak niesprawiedliwym, według niego, świecie. Żal mu krzewu, rozczula się on nad małą roślinką, a nad Niniwą, wielkim miastem, gdzie znajduje się sto dwadzieścia tysięcy ludzi i mnóstwo zwierząt, już niekoniecznie. Czy odczuje w końcu żal? Kim tak naprawdę jest Jonasz? Analiza narracyjna zwraca uwagę na luki w tekście i na pytania, jakie z nich wynikają, pokazując jednocześnie, że są to pytania skierowane do czytelnika, i że to on ma na nie odpowiedzieć, w przeciwnym razie opowiadanie pozostaje bez zakończenia ${ }^{1}$. Analiza narracyjna ma na celu ukazanie tego, jaką drogę do przebycia proponuje swojemu czytelnikowi opowiadanie. Każde bowiem opowiadanie jest skomponowane w taki sposób, aby wywarło na czytelniku zamierzony wpływ, a analiza narracyjna stara się odkryć, w jaki sposób została dana narracja skomponowana ${ }^{2}$.

\section{Charakterystyka Biblii hebrajskiej jako literatury starożytnej}

Właściwa interpretacja tekstu biblijnego wiąże się z właściwym stawianiem pytań do tekstu i poszukiwaniem właściwych odpowiedzi. Opowiadania Biblii hebrajskiej same rodzą wiele pytań w każdym czytelniku, który często musi zmagać się z pojawiającymi się $\mathrm{w}$ tekście zakłóceniami, powtórzeniami i napięciami. Dlaczego one występują i jak unikać szukania absurdalnych rozwiązań

1 J.L. Ska, Sincronia: analisi narrativa, s. 139.

2 R. Bartnicki, K. Kłósek, Metody interpretacji, s. 203. 
problemów wynikających z tekstu? Biblia hebrajska należy do literatury starożytnej, która rządziła się swoimi prawami, zupełnie odmiennymi od tych, które są bliskie współczesnemu czytelnikowi. Od autorów opowiadań biblijnych dzielą nas tysiące lat, stąd przypomnienie podstawowych, ale kluczowych zasad, może pomóc współczesnemu czytelnikowi w zrozumieniu sensu opowiadania biblijnego, a także w pokonaniu bariery czasowej i kulturowej, jaka dzieli go od autorów tekstu biblijnego.

Jean Louis $\mathrm{Ska}^{3}$ wyróżnia cztery podstawowe prawa, jakimi kierowali się autorzy starożytni: a) prawo starszeństwa; b) prawo zachowywania starszych tradycji; c) prawo kontynuacji i aktualizacji; d) prawo ekonomii - pisze się tylko to, co konieczne. W starożytnym świecie, w którym żyli autorzy biblijni, większą wartość miało to, co było starsze, dlatego starano się zachować starsze tradycje, które podlegały interpretacji i aktualizacji ${ }^{4}$. Już na pierwszych kartach Biblii, w Księdze Rodzaju (Rdz 1-3) znajdujemy dwa opisy stworzenia. Może dla spójności opowiadania łatwiej byłoby usunąć jedno z opisów stworzenia, ale ostatni redaktorzy Tory zachowali obydwie tradycje, chociaż z ubytkiem dla spójności całości opowiadania. Istnieją teksty, w których redaktorzy łączyli dwie różne wersje, splatając je w jedno opowiadanie (Wj 14). Możemy powiedzieć, że starożytny Izrael prowadził intensywną politykę historyczną. Jak mówi J.L. Ska, Izrael nie zachowywał starszych tradycji, aby wystawić je i podziwiać w witrynie muzeum, ale zawsze po to, aby miały one wpływ na teraźniejszość. Klasycznym przykładem może być Księga Powtórzonego Prawa, która interpretuje i aktualizuje wcześniejsze tradycje. Współczesnemu czytelnikowi trudno jest sobie wyobrazić trudności starożytnego autora związane $\mathrm{z}$ jego działalnością. Pisanie wymagało wówczas dużo czasu i było bardzo kosztowne, wziąwszy pod uwagę fakt, że całą pracę wykonywano ręcznie i na bardzo drogim materiale. Było ono również dużą inwestycją, stąd starano się wykorzystać maksymalnie przestrzeń do pisania, dlatego zapisywano tylko to, co konieczne. Sądzę, że przypomnienie tych prostych, ale kluczowych zasad, może pomóc we właściwym doborze i stosowaniu metod.

3 J.L. Ska, Introduzione alla lettura del Pentateuco, s. 187-207.

4 Stąd na przykład w Pięcioksięgu zachowały się trzy różne kodeksy prawa: Prawo Przymierza (Wj 21-23), Kodeks w Księdze Powtórzonego Prawa (Pwt 12-26) i Prawo Świętości w Księdze Kapłańskiej (Kpł 17-26). 


\section{Niektóre zagadnienia z metodologii interpretacji opowiadań Biblii hebrajskiej}

Wyniki analizy tekstu przy zastosowaniu każdej metody mogą być bardzo interesujące, ale żadna metoda nie obejmuje całości dzieła, nie odpowiada na wszystkie możliwe pytania wynikające $\mathrm{z}$ tekstu. Tekst biblijny jest wielowymiarowy i każda metoda zajmuje się badaniem jednego z tych wymiarów, dysponując w tym celu pewnym, określonym zasobem narzędzi. Stąd, w zakresie badań, rodzi to pewnego rodzaju ograniczenia każdej metody, dlatego też istnieją różne podejścia do tekstu: synchroniczne i diachroniczne i każde z nich ma swoje metody. Która z metod jest najbardziej stosowną, potrzebną i skuteczną w analizie tekstu biblijnego? Odpowiedź jest prosta: najwłaściwszą metodą jest ta, jakiej domaga się sam tekst. To on dyktuje nam narzędzia, jakimi należy się posłużyć do jego analizy. Punktem wyjścia w interpretacji tekstu nie jest metoda, ale tekst i jego wnikliwa, uważna lektura.

Analiza narracyjna jest jedną z metod synchronicznego podejścia do tekstu biblijnego, nie zajmuje się więc historią jego kompozycji, ale nim samym, traktując go jako autonomiczną całość. Jak wspomnieliśmy jest metodą przeznaczoną wyłącznie do analizy tekstów z gatunku literackiego, jakim jest opowiadanie, a właściwe jej stosowanie to takie, które szanuje jej ograniczenia i respektuje jej synchroniczny charakter i narzędzia, jakimi ona się posługuje, dla celów spójnych z jej naturą. Należy również podkreślić, że w kompleksowych badaniach tekstu biblijnego, poszczególne metody są niezbędne i się uzupełniają.

\section{Podstawowe aspekty i etapy analizy narracyjnej opowiadań Biblii hebrajskiej}

Pierwszorzędnym celem analizy narracyjnej jest wniknięcie w świat opowiadania. W tym wypadku pytanie o właściwą metodologię analizy narracyjnej jest pytaniem o narzędzia, jakimi się ona posługuje. Jak wejść w kontakt $\mathrm{z}$ analizowanym tekstem?5 Jaki tok analizy przyjąć? Analiza narracyjna posiada cały wa-

5 Jak wejść w kontakt $\mathrm{z}$ danym tekstem? Nie ma innej drogi, jak uważne czytanie w języku oryginalnym, a następnie jego tłumaczenie. To oczywiście wymaga znajomości języka hebrajskiego. Odkrywanie sensu opowiadania związane jest nierozerwalnie $\mathrm{z}$ doświadczeniem czytania. Po ustaleniu granic tekstu należy dokonać jego streszczenia, które pozwala na posiadanie krótkiej, syntetycznej informacji o narracji: co się wydarzyło, kto jest głównym bohaterem, jak zaczyna się i kończy akcja, jaka jest różnica pomiędzy sytuacją wyjściową i końcową w opowiadaniu, jakie są istotne elementy fabuły. 
chlarz bardzo precyzyjnych kryteriów, które znajdują zastosowanie na poszczególnych etapach analizy opowiadania. Podstawowymi aspektami opowiadania, jakimi zajmuje się analiza narracyjna są: treść opowiadania, model komunikacyjny i sposób opowiadania ${ }^{6}$. Stąd podstawowe elementy poddane badaniu w analizie narracyjnej to czas, fabuła, bohaterowie, narrator i czytelnik, punkt widzenia i styl ${ }^{7}$. Celem obecnej refleksji nie jest wyczerpujące ukazanie wszystkich aspektów analizy narracyjnej, ale przedstawienie ich w celu ukazania metodologii pracy z tekstem, dlatego zostaną zaprezentowane obecnie niektóre podstawowe elementy analizy narracyjnej, ze wskazaniem kolejnych jej etapów z punktu widzenia metodologicznego.

\subsection{Ustalenie początku i zakończenia opowiadania}

Każde opowiadanie opisuje pewne wydarzenia, zawierające w sobie początek, rozwinięcie i zakończenie, stąd pierwszym zadaniem egzegety jest dokładne ustalenie granic danego opowiadania ${ }^{8}$. W analizie narracyjnej bardzo ważne jest, aby także kryteria, które pozwalają na wyodrębnienie początku i zakończenia opowiadania, miały charakter narracyjny. W świecie opowiadania, podobnie jak i w naszym świecie, wszystko wydarza się w czasie i w przestrzeni, a mediatorem pomiędzy tymi dwoma światami, światem opowiadania i światem czytelnika, jest narrator, który opowiada historię, udziela głosu bohaterom i komentuje wydarzenia. W narracji podstawowymi elementami odróżniającymi ją od innych gatunków literackich są narrator i fabuła, oparta na idei czasowego i logicznego następstwa. Stąd pierwsze kryterium określenia granic tekstu dotyczy rozwoju akcji dramatycznej, a więc tego, kiedy główna akcja opowiadania rozpoczyna się i kończy. Kryteria dramatyczne, wskazujące na zmianę akcji to: zmiana czasu, miejsca i postaci. Inne wskazówki mają charakter stylistyczny, a są nimi: wprowadzenia, inkluzje, charakterystyczne słownictwo, wskazówki geograficzne, powtórzenia, czy zmiana gatunku literackiego ${ }^{9}$. Podobnie jak ustalenie granic tekstu ważna jest analiza kontekstu bliższego i dalszego, w jakim dane opowiadanie występuje.

R. Bartnicki, K. Kłósek, Metody interpretacji, s. 201-243.

7 J.L. Ska, "I nostri padri”, s. 23-147.

8 A. Węgrzyn, Postawy wobec Jezusa, s. 47.

9 J.L. Ska, "I nostri padri", s. 15-17. 


\subsection{Analiza form czasownikowych}

W przypadku analizy tekstu hebrajskiego bardzo ważna jest analiza form czasownikowych, jakich użył autor do opisu rozwoju akcji, ponieważ są one siłą napędową opowiadania i stanowią o dynamice akcji. Oczywiście do tego potrzebna jest znajomość języka hebrajskiego. Autorzy biblijni używają różnych form czasownikowych, by wskazać na hierarchię ważności opisywanych czynności. Do opisu czynności, dokonujących się na pierwszym planie, najczęściej używaną formą czasownikową jest wayyiqtol, która opisując łańcuch następujących po sobie czynności dokonanych, tworzy jakby „kręgosłup” opowiadania. Dla przykładu: Wtedy Jakub podał Ezawowi chleb i soczewicę. Ezaw najadł się $i$ napit, a potem wstał $i$ oddalit się. Tak to Ezaw zlekceważyt przywilej pierworodztwa ( $\operatorname{Rdz} 25,34)$.

$\mathrm{Na}$ drugim planie znajdują się czynności trwające w czasie (wyrażone w formie imiesłowu) i powtarzające się (opisane w formie yiqtol i weqatal). Zwykle te czynności nie mają bezpośredniego wpływu na postęp akcji. Dla przykładu: Pan ukazat sie Abrahamowi pod dębami Mamre, gdy ten siedziat u wejścia do namiotu w najgorętszej porze dnia (Rdz 18,1). Główną czynnością, występującą na pierwszym planie, jest ukazanie się Pana Abrahamowi. Sam zaś Abraham i jego czynność znajduje się w tle. W pierwszym wypadku użyty został czasownik har $\mathrm{w}$ formie wayyiqtol, $\mathrm{w}$ drugim zaś występuje czasownik bvy $\mathrm{w}$ formie imiesłowu.

Następowanie po sobie dwóch form czasownikowych wayyiqtol i qatal ${ }^{10}$ stanowi konstrukcję, która może mieć co najmniej trzy funkcje: a) wskazywać na ścisły związek logiczny pomiędzy dwiema czynnościami b) wyrażać chronologiczną jednoczesność dwóch czynności; c) może również wskazywać na czynność odzyskaną, to znaczy dokonaną wcześniej, o której wspomina się później.

Innego rodzaju analizy czasowników dokonuje się w przypadku występujących w opowiadaniu dialogów, biorąc pod uwagę rodzaj wypowiedzi ${ }^{11}$. Specyficznym rodzajem wypowiedzi jest narracja $w$ narracji, kiedy jeden $\mathrm{z}$ bohaterów opowiada jakieś wydarzenie.

10 A. Niccacci, Sintassi del verbo ebraico, 22.

11 J.L. Ska, "I nostri padri", s. 14-15. Autor wyróżnia dwie formy wypowiedzi: „discorsi predittivi” odnoszące się do przyszłości, w które najczęściej rozpoczynają się od czasowników w formie yiqtol, po której następuje seria czasowników w formie $w^{e}$ qatal i „discorsi esortativi”, w których najczęściej występującą formą jest tryb rozkazujący. 


\subsection{Analiza czasu}

Analiza narracyjna dokonuje bardzo ważnego rozgraniczenia pomiędzy historia i opowiadaniem. Pomijając kwestię różnorodności terminologii, w zależności od poszczególnych autorów, należy doprecyzować, że historia jest abstrakcyjną rekonstrukcją, w której czytelnik umieszcza elementy opowiadania według ich chronologicznego i logicznego porządku i uzupełnia to, czego brakuje. Opowiadanie natomiast jest konkretną narracją w jej ostatecznym kształcie, w której motywy ułożone są według porządku i wzajemnych relacji zamierzonych przez autora ${ }^{12}$. Krótko rzecz ujmując, opowiadanie jest historią opowiedzianą w określony sposób właściwy autorowi i przy użyciu jego własnych strategii.

W związku z chronologią, która występuje w każdej narracji, fundamentalnym $\mathrm{w}$ analizie narracyjnej jest pojęcie czasu i rozróżnienie pomiędzy czasem historii, który jest czasem trwania wydarzeń prezentowanych w narracji, i czasem opowiadania, to znaczy po prostu czasem potrzebnym na opowiedzenie wydarzeń, który mierzy się długością tekstu. Na przykład w Rdz 29,20 czytamy: I tak stużył Jakub za Rachele przez siedem lat, a wydały mu się one jak dni kilka, bo bardzo miłowat Rachele. W tym wypadku czas historii trwa 7 lat, zaś czas opowiadania to zaledwie kilka słów ${ }^{13}$. Takie porównanie pozwala na ustalenie ważności opisywanych wydarzeń. Należy również zauważyć, że w streszczeniach czas opowiadania jest bardzo krótki w stosunku do czasu opowiadanego. Zupełnie odwrotnie jest w scenach, zwłaszcza w dialogach, gdzie jest on prawie taki sam.

Innym ważnym kryterium jest analiza porządku opowiadanych wydarzeń, który w opowiadaniu może odbiegać od porządku wydarzeń w historii. Czasami autor biblijny opowiada jakieś wydarzenie po fakcie (analepsis) ${ }^{14}$ lub też celowo antycypuje wydarzenia, uprzedzając fakty (prolepsis). Przykładem analepsis, czyli powrotu do przeszłości, może być fragment w opowiadaniu o Józefie ( $\operatorname{Rdz} 42,21)$, kiedy jego bracia wspominają: Ach, zawiniliśmy przeciwko bratu naszemu, patrzac na jego strapienie, kiedy nas błagał o litość, a nie wysłu-

12 Ibidem, s. 20-21.

13 Innym przykładem może być opowiadanie o podróży Jakuba do wuja Labana, która musiała trwać wiele tygodni z uwagi na dużą odległość. Wyznacza on czas historii, z którego relacja w opowiadaniu zajmuje 12 wersetów i dotyczy wizji w Betel (Rdz 28,10-22). Innym przykładem może być Księga Powtórzonego Prawa, która zawiera mowy Mojżesza wygłoszone w ostatnim dniu jego życia (Pwt 1,3). Tak więc czas historii trwa jeden dzień, a czas opowiadania aż 34 rozdziały.

14 J.N. Aletti, Lessico ragionato, s. 73. Zjawisko to nazywa się również flashback, to znaczy wspomnienie, retrospekcyjny powrót do przeszłości. 
chaliśmy go! Do tego momentu czytelnik nie znał reakcji Józefa na spisek braci. W Rdz 37 nic się nie mówi o błaganiu Józefa o litość. Natomiast przykładem prolepsis mogą być w tej samej historii sny Józefa, które uprzedzają wydarzenia $(\operatorname{Rdz} 37,5-10)$.

Luki w opowiadaniu są bardzo ważnym narzędziem w ręku narratora, są one przez niego zaplanowane i najczęściej wypełnione przez późniejsze podanie informacji o wydarzeniach czy motywach działania bohaterów. W opowiadaniu o Jonaszu, od samego początku czytelnik zadaje sobie pytanie wynikające z luki, jaką tworzy brak informacji na temat prawdziwych motywów jego działania: dlaczego Jonasz nie poszedł do Niniwy. Czyżby tak bardzo bał się tego wielkiego miasta? Dlaczego ucieka przed Bogiem do Tarszisz? Relacja pomiędzy czasem historii i czasem opowiadania tworzy rytm narracji, w którym akcja może zostać przyspieszona, jak w Rdz 25,34: Ezaw najadt się i napit, a potem wstał $i$ oddalił się i zlekceważył przywilej pierworodztwa, albo także zwolniona, a nawet całkowicie zatrzymana, kiedy pojawiają się opisy i wtrącenia narratora. Jak widzimy, czas w narracji jest nie tylko konieczny do tego, aby w ogóle stworzyć opowiadanie, ale jest narzędziem pewnej strategii narracyjnej.

\subsection{Analiza fabuły i jej rozwoju}

Fabuła jest fundamentalnym i dynamicznym elementem opowiadania i jeśli by jej zabrakło, to nie tylko zabrakłoby dynamiki w opowiadaniu, ale nie byłoby opowiadania. Jak mówi Arystoteles ${ }^{15}$, fabuła (mythos) jest „uporządkowanym połączeniem faktów". Jeśli zabrakłoby tego łańcucha, który zespala wszystkie inne elementy opowiadania, zabrakłoby opowiadania. Można wtedy mówić o postaciach i ich pojedynczych czynnościach, nie zaś o opowiadaniu. Temu istotnemu elementowi opowiadania poświęcimy miejsce w odrębnym opracowaniu.

\subsection{Charakterystyka bohaterów}

Innym elementem opowiadania, jakim zajmuje się analiza narracyjna, są postaci w nim występujące. Opowiadania biblijne posługują się różnymi sposobami charakteryzacji bohaterów, np.: przez odpowiednio dobrane imię bohatera, jego przedstawienie na początku lub podczas opowiadania, ujawnienie jego myśli, snów i wyroczni lub też dialogów z innymi bohaterami.

Należy jednak powiedzieć, że w opowiadaniach biblijnych te zabiegi nie są ukierunkowane na ukazanie wewnętrznych przeżyć bohaterów, ale na wskaza-

15 Arystoteles, Poetyka, 1450a. 
nie motywów ich działania. Celem analizy narracyjnej jest nie tyle rekonstrukcja procesów mentalnych bohaterów, ile raczej ukazanie ich roli w rozwoju fabuły i to, jak ich cechy warunkują rozwój akcji w opowiadaniu ${ }^{16}$. Istniejące w Biblii opisy bohaterów są raczej krótkie: Rdz 25, 25-27 (Jakub i Ezaw) ${ }^{17}$; 29,17 (Lea i Rebecca) ${ }^{18}$, czy opis Goliata w 1 Sam 17,4-7, który jest jednym $\mathrm{z}$ najdłuższych opisów sylwetki bohatera ${ }^{19}$. Bohaterowie narracji są nierozerwalnie związani z fabułą, wykonują oni rożne działania lub je determinują, wpływając w ten sposób na fabułę ${ }^{20}$.

Analiza narracyjna używa różnych kryteriów klasyfikacji bohaterów: według ich rozwoju w opowiadaniu (dynamiczni lub statyczni), czy też w zależności od roli, jaką zajmują (główny bohater, protagonista, antagonista, postaci drugoplanowe). W analizie fundamentalne znaczenie ma dokładne ustalenie funkcji każdej postaci występującej w fabule. Na przykład w historii Józefa w Rdz 37-50, Juda ma decydujący wpływ na rozwój fabuły, Ruben zaś jest uosobieniem „kontrastu”, jego reakcje są niewłaściwe, dlatego przygotowują i podkreślają decydujący wpływ trafnych interwencji Judy ${ }^{21}$.

\subsection{Dialog pomiędzy narratorem i czytelnikiem}

Opowiadanie jest pewnym rodzajem komunikacji, przesłaniem narratora skierowanym do odbiorcy opowiadania. Klasyczny model komunikacyjny zawiera następujące elementy: autor rzeczywisty, autor domyślny, narrator, narracja, odbiorca narracji, czytelnik domyślny i czytelnik rzeczywisty. We właściwym zastosowaniu analizy narracyjnej bardzo ważne jest jasne odróżnienie poszcze-

16 J.L. Ska, Sincronia: analisi narrativa, s. 159-162.

17 Gen 25,25-27: „I wyszedł pierwszy syn czerwony, cały pokryty owłosieniem, jakby płaszczem; nazwano go więc Ezaw. Zaraz potem ukazał się brat jego, trzymający Ezawa za piętę; dano mu przeto imię Jakub. - Izaak miał lat sześćdziesiąt, gdy mu się oni urodzili. A gdy chłopcy urośli, Ezaw stał się zręcznym myśliwym, żyjącym w polu. Jakub zaś był człowiekiem spokojnym, mieszkającym w namiocie”.

18 Rdz 29,17: „Oczy Lei były jakby zgaszone, Rachela zaś miała piękną postać i miłą powierzchowność".

191 Sam 17,4-7: „Wtedy wystąpił z obozu filistyńskiego pewien harcownik imieniem Goliat, pochodzący z Gat. Był wysoki na sześć łokci i jedną piędź. ${ }^{5}$ Na głowie miał hełm $\mathrm{z}$ brązu, ubrany zaś był w łuskowy pancerz $\mathrm{z}$ brązu o wadze pięciu tysięcy syklów. ${ }^{6}$ Miał również na nogach nagolenice $\mathrm{z}$ brązu oraz brązowy, zakrzywiony nóż w ręku. ${ }^{7}$ Drzewce włóczni jego było jak wał tkacki, a jej grot ważył sześćset syklów żelaza. Poprzedzał go też giermek niosący tarczę".

20 R. Bartnicki, K. Kłósek, Metody interpretacji, s. 223.

21 J.L. Ska, Sincronia: analisi narrativa, s. 160-161. 
gólnych elementów. Na przykład w 2 Sam 12,1-15 prorok Natan opowiada Dawidowi przypowieść: Natan jest więc narratorem, a Dawid odbiorcą narracji. Autorem domyślnym jest osoba, która stworzyła ten epizod z zamiarem formowania czytelnika, do którego chciał on skierować swe opowiadanie. Autorem rzeczywistym jest redaktor opowiadania, a rzeczywistymi czytelnikami są osoby, które je czytają ${ }^{22}$.

W kontekście pytania o właściwą metodologię, należy zauważyć, że kiedy analiza narracyjna stara się zidentyfikować autora domyślnego i czytelnika domyślnego, metoda ta nie może nie zmierzyć się z niektórymi problemami natury historycznej, ponieważ zarówno autor, jak i czytelnik domyślny wywodzą się z konkretnego środowiska historycznego. Koniecznym staje się więc umieszczenie świata opowiadania w świecie historycznym i realnym, do którego narrator się odnosi. Opowiadania biblijne zakorzenione są w konkretnym świecie i chcą ten konkretny świat zmieniać. Należy też zauważyć, że ta interakcja stanowi zasadniczy przedmiot badań w analizie narracyjnej ${ }^{23}$.

Odnośnie do czytelnika warto powiedzieć o tym, że narrator może obdarzać go różnymi poziomami wiedzy w stosunku do bohaterów opowiadania. Czytelnik może wiedzieć tyle samo co bohaterowie albo więcej lub mniej. W Rdz 22 czytelnik wie więcej niż Abraham, a Abraham wie więcej aniżeli jego syn Izaak. Na początku historii Jonasza czytelnik wie mniej aniżeli bohater, nie wie, dlaczego Jonasz ucieka do Tarszisz. Często te różnice wiedzy są źródłem ironii, która pochodzi z kontrastu.

\subsection{Perspektywa}

Tę samą historię można opowiedzieć na różny sposób. On to nadaje kształt opowiadaniu i wpływa na zainteresowanie czytelnika opowiadaniem. Analiza zmiany perspektywy w opowiadaniu biblijnym jest związana $\mathrm{z}$ kwestią percepcji. Przedmiotem badania jest punkt widzenia, $\mathrm{z}$ jakiego w opowiadaniu opisywane są postaci i wydarzenia. Możemy wyróżnić trzy różne perspektywy: zerowa, kiedy rzeczywistość opowiadana ukazywana jest z pozycji wszechwiedzącego narratora ( $\mathrm{Rdz} 1)$, wewnętrzna, kiedy rzeczywistość przedstawiona jest z punktu widzenia percepcji jednego $\mathrm{z}$ bohaterów i zewnętrzną, kiedy widzenie rzeczywistości pochodzi od neutralnego obserwatora.

Na przykład w opowiadaniu o krzewie płonącym w Wj 3,1-4 narracja rozpoczyna się od perspektywy zewnętrznej, neutralnego obserwatora: Gdy Moj-

22 Ibidem, s. 163.

23 Ibidem, 164. Autor zauważa, że jest prawie pewny, że rozbieżności, napięcia, powtórzenia w opowiadaniu zmuszają nas do odkrycia wielu autorów tego samego opowiadania. 
żesz pasał owce swego teścia, Jetry, kapłana Madianitów, zaprowadził pewnego razu owce w głąb pustyni i przyszedł do góry Bożej Horeb.

Następnie zmienia się na zerowa, percepcja należy do wszechwiedzącego narratora, który ujawnia czytelnikowi, że Mojżeszowi objawia się Anioł Pański: ${ }^{2}$ Wtedy ukazał mu się Anioł Pański w płomieniu ognia, ze środka krzewu.

W tym momencie obiektyw kamery przesuwa się i czytelnik widzi rzeczywistość oczyma Mojżesza: Mojżesz widział, jak krzew płonął ogniem, a nie spłoną od niego. ${ }^{3}$ Wtedy Mojżesz powiedział do siebie: «Podejdę, żeby się przyjrzeć temu niezwykłemu zjawisku. Dlaczego krzew się nie spala?» Jest to perspektywa wewnętrzna.

Następna zmiana perspektywy następuje w momencie, kiedy Bóg widzi Mojżesza, który się zbliża: ${ }^{4}$ Gdy zaś Pan ujrzał, że Mojżesz podchodzit, żeby się przyjrzeć. Perspektywa Boga jest jednocześnie punktem widzenia wszechwiedzącego narratora, a więc perspektywa jest zerowa.

Jaki jest cel analizy tej strategii narracyjnej? Sama strategia pozwala czytelnikowi widzieć rzeczywistość opowiadaną trójwymiarowo, a analiza tej taktyki pozwala nam poznać dokładnie warsztat narratora i zobaczyć, w jaki sposób wprowadza on czytelnika w świat opowiadania. Warto zauważyć, że w opowiadaniu o krzewie płonącym, dzięki zmianom perspektywy, narrator pozwala czytelnikowi medytować Boga oczami Mojżesza ${ }^{24}$.

\section{Zakończenie}

Zaprezentowana powyżej metodologia dotyczy niektórych podstawowych elementów analizy narracyjnej, a kolejność ich badania wydaje się najbardziej skuteczna. Nie można poznać narratora i sposobu opowiadania, dopóki nie pozna się tekstu i nie podda się analizie elementów treści opowiadania. Analiza narracyjna w swej metodologii bardziej aniżeli jednakową formę, którą przykłada się do każdego materiału, przypomina „szycie ubrania na miarę”. Stąd najwłaściwszą metodologią i procedurą badawczą w analizie narracyjnej wydaje się ta, która najlepiej pozwala odkryć, jak dany tekst funkcjonuje. Dlatego kryteria, które zostały powyżej zaprezentowane, mają raczej charakter wskazówek dla kogoś, kto chce poruszać się po świecie opowiadania.

Czy istnieje zatem możliwość wypracowania jakiejś jednej procedury badawczej w analizie narracji biblijnych? Wydaje się oczywiste, że w żadnej procedurze badawczej nie może zabraknąć analizy istotnych elementów opo-

24 Podobny sposób opowiadania stosuje narrator w innych teofaniach $(\mathrm{Rdz} 18$ i Rdz 28). 
wiadania, ale i te działania badawcze mogą, w zależności od tekstu, okazać się mniej lub bardziej skuteczne. Poza tym, nie można zawężać badania tekstu tylko do analizy jego podstawowych elementów. Badania nad tekstem, jak mawiał Louis Alonso Schökel, przypominają bardziej sztukę aniżeli naukowe dywagacje. Cały kunszt analizy narracyjnej polega na tym, aby odkryć wyjątkowość danej narracji, a ta często kryje się w szczegółach, możliwych do odkrycia tylko dla czytelnika uważnego, doświadczonego i obdarzonego odpowiednią wrażliwością.

\section{Bibliografia}

Aletti J.N., Gilbert M., Ska J.L., De Vulpillières S., Lessico ragionato dellesegesi biblica. Le parole, gli approcci, gli autori, Brescia 2006.

Bartnicki R., Kłósek K., Metody interpretacji Nowego Testamentu. Wprowadzenie, Kraków 2014.

Niccacci A., Sintassi del verbo ebraico nella nella prosa biblica classica, Gerusalemme 1986.

Pawłowski Z., Narracja i egzystencja. Genesis w hermeneutyce opowieści, Toruń 2013.

Ska J.L., Sincronia: analisi narrativa, w: H. Simian-Yofre (red.), Metodologia dell'Antico Testamento, Bolonia 2002, s. 139-170.

Ska J.L., Introduzione alla lettura del Pentateuco. Chiavi per l'interpretazione dei primi cinque libri della Bibbia, Bolonia 2000.

Ska J.L., "I nostri padri ci hanno raccontato". Introduzione allanalisi dei racconti dell'Antico Testamento, Bologna 2012.

Węgrzyn A., Postawy wobec Jezusa ofiarującego miłość. Analiza narracyjna (Łk 7,36-50), Lublin 2016. 